\title{
Impact of Apolipoprotein E (ApoE) Polymorphism on Brain ApoE Levels
}

\author{
David R. Riddell, Hua Zhou, Kevin Atchison, Helen K. Warwick, Peter J. Atkinson, Julius Jefferson, Lin Xu, \\ Suzan Aschmies, Yolanda Kirksey, Yun Hu, Erik Wagner, Adrienne Parratt, Jane Xu, Zhuting Li, Margaret M. Zaleska, \\ J. Steve Jacobsen, Menelas N. Pangalos, and Peter H. Reinhart \\ Discovery Neuroscience, Wyeth Research, CN8000, Princeton, New Jersey 08543
}

Inheritance of the apoE4 allele $(\varepsilon 4)$ increases the risk of developing Alzheimer's disease; however, the mechanisms underlying this association remain elusive. Recent data suggest that inheritance of $\varepsilon 4$ may lead to reduced apoE protein levels in the CNS. We therefore examined apoE protein levels in the brains, CSF and plasma of $\varepsilon 2 / 2, \varepsilon 3 / 3$, and $\varepsilon 4 / 4$ targeted replacement mice. These apoE mice showed a genotype-dependent decrease in apoE levels; $\varepsilon 2 / 2>\varepsilon 3 / 3>\varepsilon 4 / 4$. Next, we sought to examine the relative contributions of apoE4 and apoE3 in the $\varepsilon 3 / 4$ mouse brains. ApoE4 represented $30-40 \%$ of the total apoE. Moreover, the absolute amount of apoE3 per allele was similar between $\varepsilon 3 / 3$ and $\varepsilon 3 / 4$ mice, implying that the reduced levels of total apoE in $\varepsilon 3 / 4$ mice can be explained by the reduction in apoE4 levels. In culture medium from $\varepsilon 3 / 4$ human astrocytoma or $\varepsilon 3 / 3, \varepsilon 4 / 4$ and $\varepsilon 3 / 4$ primary astrocytes, apoE4 levels were consistently lower than apoE3. Secreted cholesterol levels were also lower from $\varepsilon 4 / 4$ astrocytes. Pulse-chase experiments showed an enhanced degradation and reduced half-life of newly synthesized apoE4 compared with apoE3. Together, these data suggest that astrocytes preferentially degrade apoE4, leading to reduced apoE4 secretion and ultimately to reduced brain apoE levels. Moreover, the genotype-dependent decrease in CNS apoE levels, mirror the relative risk of developing $\mathrm{AD}$, and suggest that low levels of total apoE exhibited by $\varepsilon 4$ carriers may directly contribute to the disease progression, perhaps by reducing the capacity of apoE to promote synaptic repair and/or $\mathrm{A} \beta$ clearance.

Key words: apolipoprotein E; astrocyte; degradation; Alzheimer's disease; immunoassay; liver X receptor

\section{Introduction}

Apolipoprotein E (apoE) is a well characterized $34 \mathrm{kDa}$ protein that assists in the regulation of lipid metabolism (Weisgraber and Mahley, 1996). ApoE is expressed throughout the brain, and is produced by astrocytes that secrete apoE as part of a cholesterolrich lipoprotein particle (Boyles et al., 1985). ApoE in the brain is derived from local synthesis with little contribution from the periphery (Fernández-Miranda et al., 1997). In humans, apoE has three major protein isoforms: apoE2 (cys112, cys158), apoE3 (cys112, $\arg 158)$, and apoE4 ( $\arg 112, \arg 158)$. The association of allele four of apoE $(\varepsilon 4)$ as a genetic risk factor for Alzheimer's disease $(\mathrm{AD})$ has been well established, accounting for between $50-60 \%$ of the genetic variation in the disease (Corder et al., 1993; Raber et al., 2004). Patients expressing the $\varepsilon 4$ allele have an earlier age at onset, a greater amyloid burden and reduced capacity for synaptic plasticity (Corder et al., 1993, 2004; Ji et al., 2003; Lai et al., 2006). In contrast, inheritance of $\varepsilon 2$ has been associated with a decreased risk for developing AD. $\varepsilon 4$ also appears to be a risk factor for poor outcome after head trauma (Friedman et al., 1999), cerebral hemorrhage (O’Donnell et al., 2000), and stroke (Schneider et al., 2005), as well as influencing the age of onset of

\footnotetext{
Received Aug. 1, 2007; revised Aug. 4, 2008; accepted Aug. 15, 2008

This work was supported by Wyeth Pharmaceuticals.

Correspondence should be addressed to Dr. David R. Riddell at the above address. E-mail: riddeld@wyeth.com. D0I:10.1523/JNEUROSCI.1972-08.2008

Copyright $\odot 2008$ Society for Neuroscience ～0270-6474/08/2811445-09\$15.00/0
}

other neurodegenerative diseases such as Parkinson's disease (Pankratz et al., 2006), multiple sclerosis (Fazekas et al., 2001; Enzinger et al., 2004) and amyotrophic lateral sclerosis (Moulard et al., 1996). Although not all of these associations have been consistently replicated (Siddique et al., 1998; Jasinska-Myga et al., 2007; Guerrero et al., 2008). However, together, these data do suggest that apoE plays a role in the pathophysiology of a wide range of neurological conditions, not only $\mathrm{AD}$.

Despite knowing for over a decade that apoE4 is a risk factor for multiple neurodegenerative diseases, the underlying molecular mechanisms attributing to the risk-factor activity of apoE4 remains unclear. ApoE4 has two major structural characteristics that distinguish it from apoE3 or apoE2 (Hatters et al., 2006). First, apoE4 preferentially forms a "molten globule state" that ultimately reduces the in vitro stability of apoE4 relative to the other isoforms. Second, apoE4 forms a unique salt bridge interaction between Arg-61 in the $\mathrm{N}$ terminal and Glu-255 in the carboxy-terminal domain. This domain interaction results in apoE4 preferentially binding to lower density lipoprotein particles and enhanced clearance of apoE4 from the periphery (Raffai et al., 2001). Recently, Ramaswamy et al. (2005) published data to suggest that engineering an apoE4-like, Arg-61 domain interaction into murine apoE also affects CNS apoE biology and leads to low brain levels of apoE. Here, we confirm and expand on the findings of Ramaswamy et al. (2005); we demonstrate that astrocytes preferentially degrade apoE4, leading to reduced apoE4 se- 
cretion and reduced brain apoE levels. Moreover, the genotypedependent decrease in CNS apoE levels mirror the relative risk of developing $\mathrm{AD}$ and suggest that low levels of total apoE exhibited by $\varepsilon 4$ carriers may directly contribute to the disease progression.

\section{Materials and Methods}

Animals. Twelve- to twenty-week-old male $\varepsilon 2 / 2, \varepsilon 3 / 3, \varepsilon 3 / 4$ and $\varepsilon 4 / 4$ targeted replacement mice were purchased from Taconic. The mice were individually housed for at least 2 weeks before any testing and allowed $a d$ libitum access to food and water. Animal experiments were approved by the Institutional Animal Care and Use Committee of Wyeth Research. The evening before the experiment the animals were fasted. The following day the mice were anesthetized using isoflurane, plasma and CSF harvested, saline perfused and the brains removed. CSF was collected as previously described (DeMattos et al., 2002). Each brain was hemisected and frontal cortex and/or hippocampus dissected and weighed. Tissues were homogenized at a ratio of $10 \mathrm{ml} / \mathrm{g}$ wet-weight brain in ice-cold detergent-rich lysis buffer (50 mm Tris- $\mathrm{HCl}, \mathrm{pH} 8.0,150 \mathrm{~mm} \mathrm{NaCl}, 0.1 \%$ SDS, $0.5 \%$ IGEPAL CA-630, 0.5\% sodium deoxycholate, and Complete protease inhibitors; Roche) using a 10-20 s burst in Polytron homogenizer. Such a detergent-rich lysis buffer has been shown to inhibit apoE oligomerization and fully release the lipid-bound apoE epitopes which, if not exposed, may hamper accurate detection of apoE levels by immunoassay (Krul and Cole, 1996; Ramaswamy et al., 2005). The homogenates were centrifuged at 14,000 rpm for $10 \mathrm{~min}$ at $4^{\circ} \mathrm{C}$ in an Eppendorf 5417-R refrigerated Microfuge. The supernatant was collected and analyzed for apoE levels.

Immunoassays. Human apoE2, apoE3 and apoE4 standards were purchased from Calbiochem. Total apoE and apoE4 in cell culture media or brain homogenates were measured by a double-sandwich Mesoscale diagnostics (MSD)-based immunoassay (Riddell et al., 2007). Briefly, 96well streptavidin-coated MSD plates were washed three times in Trisbuffered saline containing $0.1 \%$ Tween 20 (TBST). Ten microliters of tissue culture supernatant, diluted brain homogenates or human apoE standards were loaded into wells together with $90 \mu \mathrm{l}$ of 1:5000 biotinylated goat anti-human apoE (Biodesign; K741808) in MSD blocker A. Plates were incubated overnight at $4^{\circ} \mathrm{C}$ while shaking. The following day, the plates were then washed three times in TBST and then incubated with $100 \mu$ l of detection antibody mastermix (1:5000 anti-human pan-apoE monoclonal antibody (Millipore Bioscience Research Reagents; Mab1062) and 1:10000 anti-mouse MSD-Tag in MSD blocker A) for $2 \mathrm{~h}$. For the apoE4 selective immunoassay the anti-human pan-apoE antibody was replaced with 1:5000 anti-human apoE4 monoclonal antibody (MBL International; M067-3). The plates were then washed three times in TBST and $150 \mu$ l of MSD read buffer-T was added to each well. Plates were read in a Sector Imager 6000. To ensure that the apoE measured in the brain homogenates remained in the linear range of the immunoassay, three brain homogenates from each genotype were preassayed in triplicate at 1:10, 1:20, 1:30 and 1:40 dilutions in lysis buffer. The 1:30 dilutions were determined to be the optimum dilution for brain apoE homogenates. ApoE knockout brain homogenates were used as a negative control for this assay. Protein in each sample was measured using the micro BCA protein assay (Pierce). All apoE measurements were normalized to total protein in the brain homogenates.

Western blot analysis of apoE. Conditioned media (10 $\mu \mathrm{l} / \mathrm{lane})$ or brain homogenates (10 or $25 \mu \mathrm{g} /$ lane) were subjected to SDS-PAGE and then transferred onto nitrocellulose membranes. After blocking with Odyssey blocking buffer (LI-COR) the membranes were incubated overnight with the goat polyclonal anti-apoE (Biodesign) or apoE4 monoclonal antibody (MBL International; M067-3) at concentrations suggested by the manufacturers. After extensive washing, the membranes were then incubated with Alexafluor-labeled secondary antibodies, after which the results were visualized and quantified using the Odyssey infra-red detection system. Anti- $\alpha$-tubulin (Upstate) was used as a loading control for brain homogenates.

Taqman quantitative RT-PCR. Total RNA was isolated from brain tissues using TRIzol reagent (Invitrogen) according to the manufacturer's protocol. RNA was purified using RNeasy spin columns (Qiagen), eluted in RNase-free water and treated with DNase I to remove any genomic DNA contamination. RNA quality and quantity were assessed on BioAnalyzer (Agilent Technologies) with RNA 6000 Nano reagents. Gene-specific mRNA analysis was performed by real-time PCR (TaqMan) on an ABI Prism 7000 sequence detection system (Applied Biosystems) according to the manufacturer's instructions. Taqman Fluorescent real-time PCR primers and probes for hApoE and $18 \mathrm{~s}$ were purchased from Applied Biosystems. Amplification was performed using standardized PCR-conditions as recommended by the manufacturer. The standard curve method was used to estimate specific mRNA concentrations. PCR results were normalized to $18 \mathrm{~s}$ levels.

Astrocytoma cell culture. The human astrocytoma cell lines CCFSTTG1, U87 and U118 were purchased from ATCC. Cells were maintained in DMEM/F12 (3:1) with 10\% fetal bovine serum. At $80-90 \%$ confluency, cells were washed with HBSS and then treated with various reagents in fresh serum-free medium (Neurobasal medium containing $25 \mathrm{~mm} \mathrm{KCl}, 2 \mathrm{~mm}$ glutamine, $100 \mathrm{U} / \mathrm{ml}$ penicillin, $100 \mu \mathrm{g} / \mathrm{ml}$ streptomycin with B27 supplementation) for 24 or $48 \mathrm{~h}$. At the end of the treatments, the conditioned media were collected for analysis and cell viability measured using the MTS [3-(4,5-dimethylthiazol-2-yl)-5-(3-carboxymethoxyphenyl)-2-(4-sulfophenyl)-2H-tetrazolium] assay (Promega). In some experiments, apoE was detected from media that was concentrated 10-fold in Vivaspin concentrators (10,000 molecular weight cutoff; Pierce) or from apoE containing lipoprotein particles (density $<1.21$ $\mathrm{g} / \mathrm{ml}$ ) that were isolated from media by density ultracentrifugation (LaDu et al., 1998).

ApoE genotyping and DNA sequencing. Genomic DNA was extracted from cells for PCR restriction fragment length polymorphism (PCRRFLP) genotyping, as described previously (Hixson and Vernier, 1990). Briefly, a 244 -bp apoE fragment was amplified by PCR $\left(35\right.$ cycles; $97^{\circ} \mathrm{C}$ for $1 \mathrm{~min}, 63^{\circ} \mathrm{C}$ for $1 \mathrm{~min}$, and $72^{\circ} \mathrm{C}$ for $1 \mathrm{~min}$ ) with the primer pair: 5'-GATCAAGCTTCCAATCACAGGCAGGAAG-3' and 5'-GATCCGGCCGCACACGTCCTCCATG- $3^{\prime}$. The amplified fragment was digested using HhaI and the products visualized on a $20 \%$ Tris-buffered EDTA polyacrylamide gels (Invitrogen). Each genotype gives a specific combination of HhaI fragment sizes: $\varepsilon 2 / 2,91$ and $83 \mathrm{bp} ; \varepsilon 3 / 3,91$ and $48 \mathrm{bp}$; $\varepsilon 4 / 4,72$ and 48 bp and a mixed genotype: $\varepsilon 2 / 3,91,83$, and 48 bp; $\varepsilon 3 / 4$, 91, 72 and 48 bp; $\varepsilon 2 / 4,91,83,72$ and 48 bp (Hixson and Vernier, 1990). For automatic DNA sequencing of PCR products, the sense primer was used on the 244-bp product purified from a 1.5\% agarose gel.

Primary astrocyte cultures. Mixed glia cultures were prepared using a protocol adapted from Marriott et al. (1995). Neonatal (postnatal days 1-3) $\varepsilon 3 / 3, \varepsilon 3 / 4$ or $\varepsilon 4 / 4$ targeted replacement mice (Taconic) were decapitated and cortices were dissected and placed into $4^{\circ} \mathrm{C}$ HBSS. Cortical tissue was cut coarsely and incubated in HBSS containing $0.025 \%$ trypsin, $0.3 \% \mathrm{BSA}$ and DNase $(40 \mathrm{mg} / \mathrm{ml})$ for $20 \mathrm{~min}$ at $37^{\circ} \mathrm{C}$. The solution was replaced by HBSS containing BSA and DNase and triturated 20 times. After allowing for debris to settle the supernatant was passed through a $40 \mu \mathrm{m}$ cell strainer (BD Biosciences) and the process was repeated twice more. The supernatant was centrifuged at $1000 \mathrm{rpm}$ for 5 min and the pellet was resuspended in $10 \mathrm{ml}$ of DMEM containing 50 units of penicillin, $50 \mathrm{mg} / \mathrm{ml}$ streptomycin and $10 \%$ heat-inactivated fetal bovine serum (Invitrogen). Suspended cells were divided into T175 flasks, grown for $10 \mathrm{~d}$ in vitro and purified by overnight shaking (120 rpm). Remaining adherent cells, containing $\sim 90 \%$ glial fibrillary acidic protein-positive astrocytes, were plated $48 \mathrm{~h}$ before experiments. At $80-$ $90 \%$ confluency, cells were washed with HBSS and incubated in fresh serum-free medium (neurobasal medium containing $25 \mathrm{~mm} \mathrm{KCl,} 2 \mathrm{~mm}$ glutamine, $100 \mathrm{U} / \mathrm{ml}$ penicillin, $100 \mu \mathrm{g} / \mathrm{ml}$ streptomycin with B27 supplementation) for $24 \mathrm{~h}$. At the end of the incubation, the conditioned media were collected for analysis. Protein concentration of the lysate was measured using Micro BCA Protein Assay Kit (Pierce). Total cholesterol levels were measured using the Amplex Red cholesterol assay kit (Invitrogen). Total apoE and apoE4 levels were measured in conditioned media using the protocol described above.

Pulse-chase experiments and metabolic labeling of cell proteins with $\left[{ }^{35} S\right]$-methionine. Pulse-chase studies were performed as described previously (Kockx et al., 2004). Primary astrocytes were prepared from $\varepsilon 3 / 3$ and $\varepsilon 4 / 4$ homozygous mice were cultured for $24 \mathrm{~h}$ in serum-free media, 
a

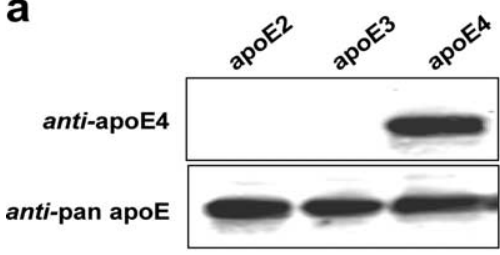

C

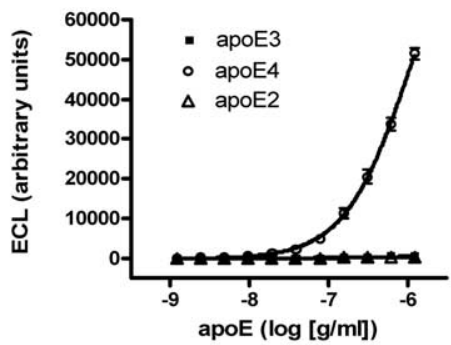

b

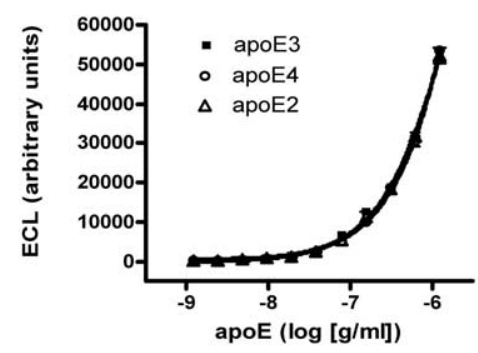

d

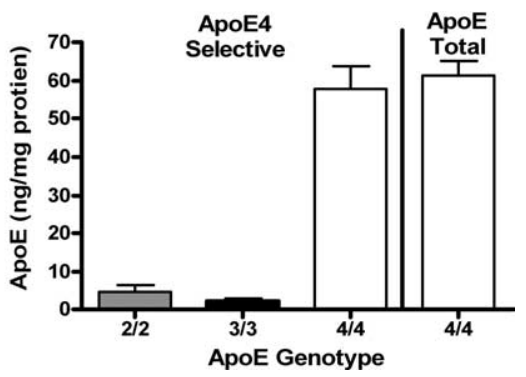

Figure 1. Development of an apoE4-specific immunoassay. $\boldsymbol{a}$, Western blotting of $1 \mu \mathrm{g} /$ lane of recombinant apoE2, apoE3 and apoE4 standards using either an apoE4 selective or a nonselective pan apoE antibody. $\boldsymbol{b}, \boldsymbol{c}, \mathrm{ApoE2}(\triangle)$, apoE3 ( $(\boldsymbol{\square})$ and apoE4 (O) standards were assayed using MSD-based homogenous immunoassays, as outlined in Materials and Methods, incorporating either the pan-apoE (b) or apoE4-specific antibodies (c). Results are expressed as MSD electrochemiluminescence (ECL) counts and each data point represents the mean \pm SEM of three independent experiments with triplicates. $\boldsymbol{d}$, Cortices from 20-weekold apoE-targeted replacement mice were detergent extracted, and apoE was measured in the tissue homogenates using either the pan-apoE immunoassay (total apoE) or the apoE4 selective assay and normalized to total protein levels as outlined in Materials and Methods ( $n=4-14$ animals per group; mean \pm SEM).

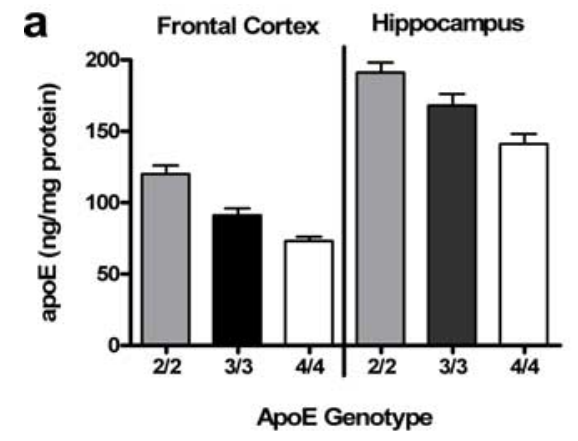

C

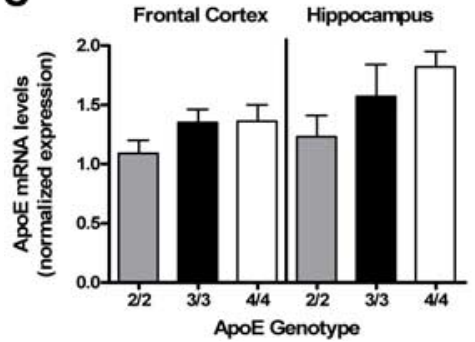

b
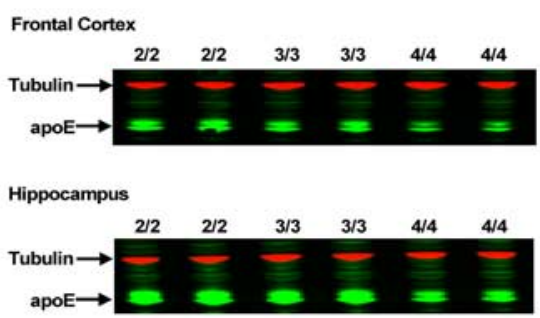

d

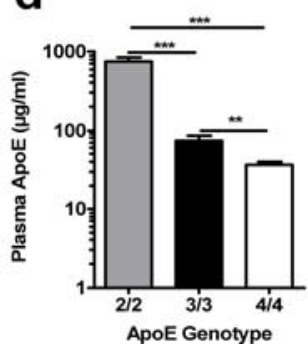

e

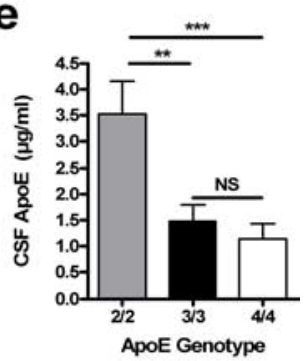

Figure 2. ApoE-targeted replacement mice have a genotype-dependent decrease in brain, CSF and plasma apoE levels. $\boldsymbol{a}$, Frontal cortex and hippocampus from 20-week-old apoE-targeted replacement mice were detergent extracted and total apoE was measured in the tissue homogenates using the pan-apoE immunoassay and normalized to total protein levels as outlined in Materials and Methods ( $n=22$ animals per group; mean \pm SEM). $\boldsymbol{b}$, Ten micrograms of cortical or hippocampal homogenates (from $\varepsilon 2 / 2, \varepsilon 3 / 3$ or $\varepsilon 4 / 4$ ) were subjected to Western blotting using a polyclonal anti-pan-apoE antibody. Anti- $\alpha$-tubulin was used as a loading control. c, mRNA expression levels of hApoE in the frontal cortex and hippocampus of 20-week-old targeted replacement mice were analyzed by quantitative real-time PCR. RNA amounts were normalized with $18 \mathrm{~s}(n=4-10$ animals per group; mean \pm SEM). $\boldsymbol{d}, \boldsymbol{e}$, Plasma (d) or CSF (e) from 20-week-old apoE-targeted replacement mice were detergent extracted, and total apoE was measured using the pan-apoE immunoassay as outlined in Materials and Methods $(n=20$ animals per group; mean \pm SEM; ${ }^{* *} p<0.01,{ }^{* * *} p<0.001$, NS, nonsignificant). washed and incubated in methionine-free DMEM with $250 \mu \mathrm{Ci} / \mathrm{ml}\left[{ }^{35} \mathrm{~S}\right]$ methionine for $3 \mathrm{~h}$. Cells were then washed and chased with serum-free media containing unlabeled methionine. $\left[{ }^{35} \mathrm{~S}\right]$-labeled apoE in cell lysates and medium was immunoprecipitated using a biotinylated goat antibody to human apoE and NeuroAvadin Agarose (Thermo Scientific). Immunoprecipitated $\left[{ }^{35} \mathrm{~S}\right]$-labeled apoE was separated by SDS-PAGE. The $34 \mathrm{kDa}$ band was quantified by phosphorimaging (Molecular Dynamics; phosphoscreen Storm 860 scanner) and expressed as arbitrary units of $\left[{ }^{35} \mathrm{~S}\right]$-apoE per milligram of cell protein.

Data analysis. All in vitro and in vivo assay data were analyzed using Graphpad Prism and statistical significance determined using either a one-way ANOVA analysis with Dunnett's post test, two-way ANOVA analysis with Bonferroni post test or two-tailed unpaired Student's $t$ test, as appropriate. Half-life values were determined by nonlinear regression (one phase exponential decay) using Graphpad Prism. All data are presented as mean \pm SEM.

\section{Results}

To accurately determine the relative amounts of total apoE and apoE4 in CNS compartments, we developed two specific immunoassays: an assay to measure total apoE regardless of isoform and an apoE4 selective assay (Fig. 1). The total apoE assay recognized all forms of apoE equally well (Fig. $1 b$ ), whereas the apoE4 assay selectively detected purified apoE4 (Fig. 1c) and apoE4 from brain lysates of homozygous $\varepsilon 4 / 4$ targeted replacement mice (Fig. $1 d$ ). Both total apoE and apoE4 assays detected equivalent levels of apoE protein in $\varepsilon 4 / 4$ lysates (total apoE, $57.9 \pm 5.8 \mathrm{ng} / \mathrm{mg}$ protein vs apoE4 $61.3 \pm 3.9 \mathrm{ng} / \mathrm{mg}$ protein, $n=14, p=0.63$ ).

Using these assays we sought to determine the absolute levels of apoE protein in the CNS. We choose not to examine apoE in over-expressing transgenic mouse models but rather examined apoE protein levels in the brains of 20 week old humanized $\varepsilon 2 / 2, \varepsilon 3 / 3$ and $\varepsilon 4 / 4$ targeted replacement mice, where the apoE expression is under the control of endogenous promoters (Knouff et al., 1999). Importantly, these mice showed a genotype-dependent decrease in cortical and hippocampal apoE levels, $\varepsilon 2 / 2$ $>\varepsilon 3 / 3>\varepsilon 4 / 4$ (cortex, $p<0.0001$; hippocampus, $p<0.0001$, one-way ANOVA) (Fig. $2 a$ ), with $\varepsilon 3 / 3$ showing a $24.0 \pm 4.1 \%$ and $\varepsilon 4 / 4$ showing a $39.4 \pm 3.3 \%$ decrease in total cortical apoE relative to $\varepsilon 2 / 2$, whereas in the hippocampus $\varepsilon 3 / 3$ had a $12.0 \pm 3.9 \%$ and $\varepsilon 4 / 4$ a $26.2 \pm 3.8 \%$ reduction relative to $\varepsilon 2 / 2$. Interestingly, apoE levels were consistently 1.5-2-fold higher in the hippocampus compared with the frontal cortex, regardless of genotype. To 
discount the possibility of a differential detection of the apoE isoforms from the brain lysates by immunoassay, we also measured apoE levels in the cortex and hippocampus using Western blotting. Using this technique we also observed a genotypedependent decrease in cortical and hippocampal apoE levels, $\varepsilon 2 / 2>\varepsilon 3 / 3>\varepsilon 4 / 4$ (Fig. $2 b$ ). Next, we assessed the levels of apoE mRNA in the cortex and hippocampus. As noted for the Arg-61 mouse (Ramaswamy et al., 2005), the levels of apoE mRNA were not significantly different across all three genotypes (Fig. $2 c$ ) implying that the altered levels of apoE are attributed to a post-translational mechanism. Next, we measured plasma levels of apoE across all three genotypes and, as reported in the human population (Eto et al., 1986), we observed a genotype-dependent decrease in plasma apoE levels (Fig. 2d). However, this time the $\varepsilon 2 / 2$ levels were 10 to 20-fold higher than that of $\varepsilon 3 / 3$ and $\varepsilon 4 / 4$ $(\varepsilon 2 / 2,758.5 \pm 78.7 \mu \mathrm{g} / \mathrm{ml}$ vs $\varepsilon 3 / 3,74.0 \mu \mathrm{g} /$ $\mathrm{ml} \pm 11.3$ vs $\varepsilon 4 / 4,37.1 \pm 2.7 \mu \mathrm{g} / \mathrm{ml})$. Finally, we measured CSF levels of apoE across all three genotypes and again observed a genotype-dependent decrease in apoE levels $(\varepsilon 2 / 2,3.5 \pm 0.6$ vs $\varepsilon 3 / 3,1.5 \pm$ 0.3 vs $\varepsilon 4 / 4,1.1 \pm 0.3 \mu \mathrm{g} / \mathrm{ml})$; however, because of the high degree of variability in CSF apoE levels within each genotype, the differences between $\varepsilon 3 / 3$ and $\varepsilon 4 / 4$ did not reach statistical significance (Fig. 2e).

Next, we sought to determine the relative contribution of apoE4 to total apoE levels in 12-week-old $\varepsilon 3 / 4$ heterozygous mice. Consistent with the genotypic decrease in 20 -week-old animals, we observed a genotype-dependent decrease in cortical and hippocampal apoE levels, $\varepsilon 3 / 3>\varepsilon 3 / 4>_{\varepsilon} 4 / 4$ in the 12 -weekold animals (cortex, $p=0.015$; hippocampus, $p=0.0015$, oneway ANOVA) (Fig. 3a). Moreover, using the apoE4 selective assay, we were able to determine the relative contribution of apoE4 to apoE3 in brain, CSF and plasma of $\varepsilon 3 / 4$ animals. In all compartments, including CSF, and in contrast to the expected equal contribution of each apoE isoform to the total apoE pool, apoE4 represented only between $30-40 \%$ of the total apoE (Fig. 3b). Moreover, in frontal cortex and hippocampus, the absolute amount of apoE3 per allele is similar between $\varepsilon 3 / 3$ and $\varepsilon 3 / 4$ mice, as is the amount of apoE4 per allele in $\varepsilon 4 / 4$ and $\varepsilon 3 / 4$ mice (Fig. $3 c, d)$. These data imply that the reduced levels of total apoE in $\varepsilon 3 / 4$ mice can be fully explained by the reduction in apoE4 levels.

To determine the molecular mechanism by which $\varepsilon 4$ allele affects apoE protein levels, we sought to characterize apoE4 levels from human astrocytoma cell lines and primary astrocytes cultured from the apoE targeted replacement mice. Initially, we apoE genotyped a range of human astrocyoma cell lines with the hope of identifying apoE4 expressing cells. We subsequently identified two astrocytomas that expressed the apoE4 isoform; CCF-STTG1 genotyped as $\varepsilon 3 / 4$ and U118 genotyped as $\varepsilon 2 / 4$ (Fig. $4 a$ ). The genotype was confirmed by DNA sequencing (Fig. $4 b$ ) and by Western blotting of astrocytoma conditioned culture media using an apoE4 selective antibody (Fig. $4 c$ ). We next attempted to measure the levels of total apoE and apoE4 secreted by b
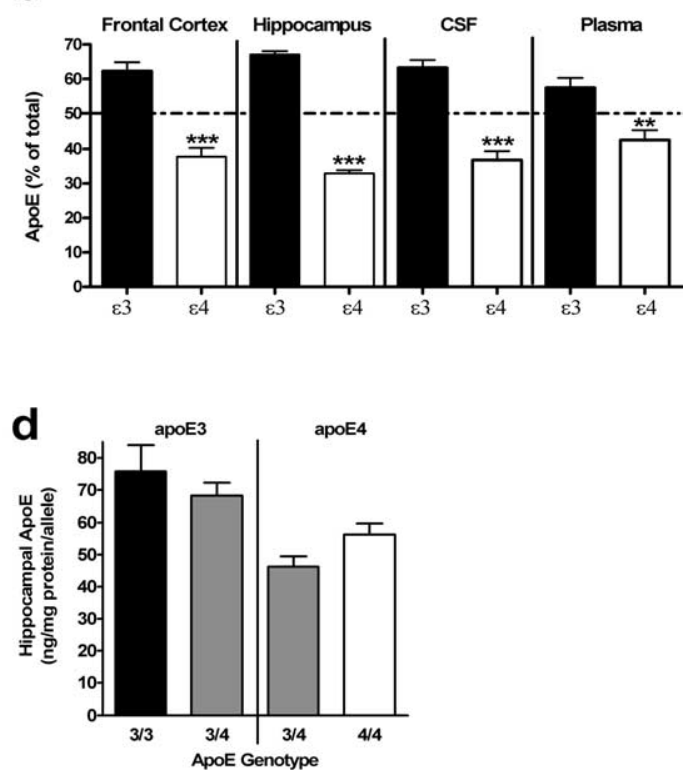

Figure 3. Heterozygous $\varepsilon 3 / 4$-targeted replacement mice have reduced levels of brain, CSF and plasma apoE4 relative to a. Frontal cortex and hippocampus from 12-week-old apoE-targeted replacement mice were detergent extracted and outlined in Materials and Methods ( $n=14-22$ animal pan-apoE immunoassay and normalized to total protein levels as plasma from 12-week-old $\varepsilon 3 / 4$-targeted replacement mice were detergent extracted and total apoE and apoE4 protein levels

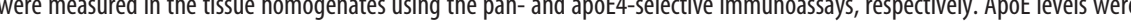

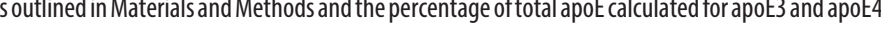
$\left(n=10-22\right.$ animals per group; mean \pm SEM; $\left.{ }^{* *} p<0.01,{ }^{* *} p<0.001\right) . \boldsymbol{c}, \boldsymbol{d}$, The amount of apoE3 or apoE4 per allele was

these cells. Although we could detect basal total apoE secretion from the CCF-STTG1 cells, apoE4 protein levels were below the sensitivity of our assay. To improve our assay signal, we sought to isolate and concentrate the astrocyte secreted apoE-containing lipoprotein particles using flotation ultracentrifugation ( $\mathrm{LaDu}$ et al., 1998). Using this technique we could robustly measure both total apoE and apoE4 from the purified astrocytic lipoproteins. We found that although the CCF-STTG1-derived lipoproteins contained $67.9 \pm 7.3 \mathrm{ng} / \mathrm{ml}$ total apoE, only $11.23 \pm 2.7 \mathrm{ng} / \mathrm{ml}$ was attributed to apoE4 protein. Thus, apoE4 represented only $16.6 \pm 4.1 \%$ of the total apoE secreted from CCF-STTG1 astrocytes (Fig. 5a). To discount the possibility of differential purification of apoE3 relative to apoE4, we sought to verify this result using a variety of apoE enrichment techniques; first, we directly concentrated the CCF-STTG1 conditioned media 10-fold, using filtration centrifugation, without lipoprotein isolation and again apoE4 represented only $23.5 \pm 2.3 \%(n=3, p<0.0001)$ of total apoE. Second, to fully remove any form of concentration protocol from our experimental design, we treated CCF-STTG1 cells with the liver X receptor (LXR) agonist, TO901317 (Quinet et al., 2004). TO901317 has recently been shown to potently induce apoE expression from astrocytes, including CCF-STTG1 cells (Liang et al., 2004). Similar to what has previously been demonstrated, we found that TO901317 potently induced total apoE expression from the cells (Fig. 5b). At all doses tested apoE4 represented $<25 \%$ of the total apoE secreted from CCF-STTG1 cells treated with TO901317. We next examined the relative apoE4 secretion levels from the U118, $\varepsilon 2 / 4$ expressing cells. In these cells, secreted apoE4 levels only represented $21.4 \pm 1.6 \%$ of the total apoE pool (Fig. 5a).

One potential explanation for the reduced levels of apoE4 in 
a

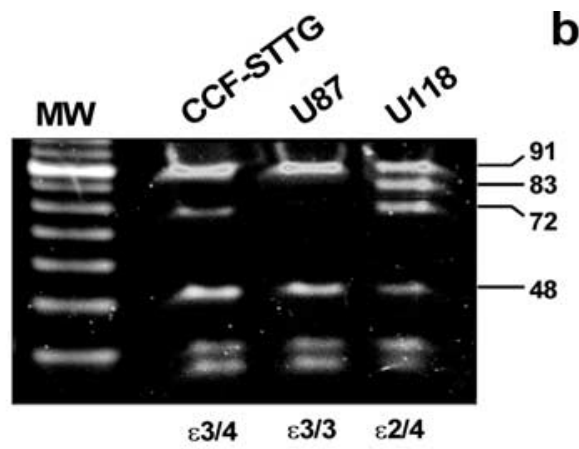

b
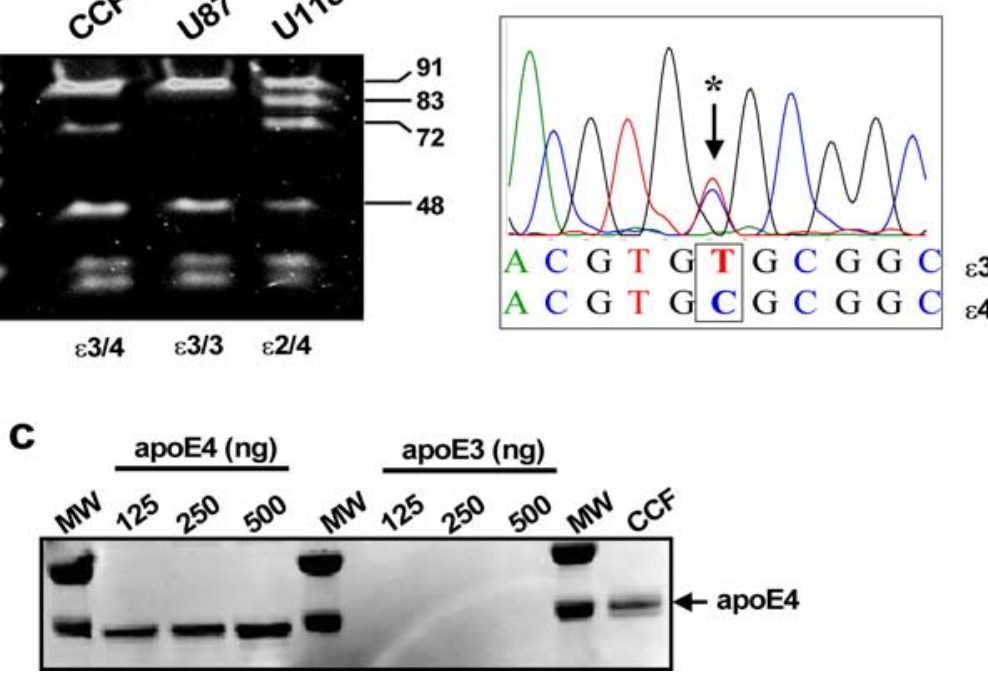

Figure 4. Identification of human astrocytomas heterozygous for the $\varepsilon 4$ allele. $\boldsymbol{a}$, ApoEgenotyping of human astrocytoma cell lines (CCF-STTG, U87 and U118) was performed by amplifying a 244-bp PCR product from exon IV and restriction isotyping with Hhal (Hixson and Vernier, 1990). Each genotype gives a specific combination of Hhal fragment sizes: $\varepsilon 2 / 2,91$ and $83 \mathrm{bp} ; \varepsilon 3 / 3,91$ and $48 \mathrm{bp} ; \varepsilon 4 / 4,72$ and $48 \mathrm{bp}$ and a mixed genotype: $\varepsilon 2 / 3,91,83$, and $48 \mathrm{bp} ; \varepsilon 3 / 4,91,72$ and $48 \mathrm{bp} ; \varepsilon 2 / 4,91,83,72$ and $48 \mathrm{bp}$. CCF-STTG1 cells were genotyped as $\varepsilon 3 / 4$, whereas U118 cells were $\varepsilon 2 / 4$. $\boldsymbol{b}$, DNA sequencing of the $244 \mathrm{bp} \mathrm{PCR} \mathrm{product} \mathrm{from}$ CCF-STTG1 cells verified that they exhibited a mixed $\varepsilon 3 / 4$ genotype at codon 112.c, Conditioned media from CCF-STTG1 cells was analyzed by Western blotting using an apoE4 selective antibody (as outlined in Materials and Methods). Purified recombinant apoE3 and apoE4 were used as standards.

a

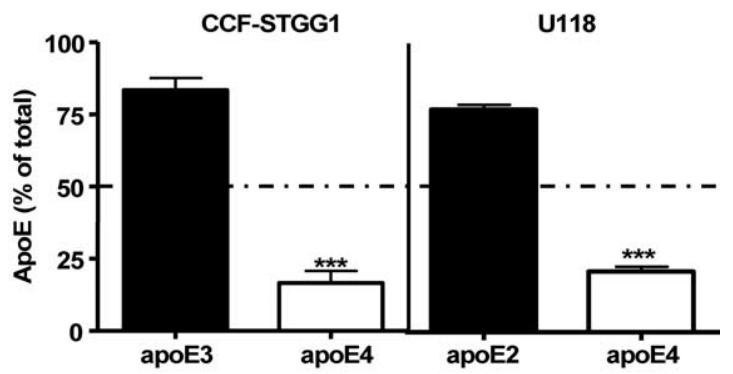

b

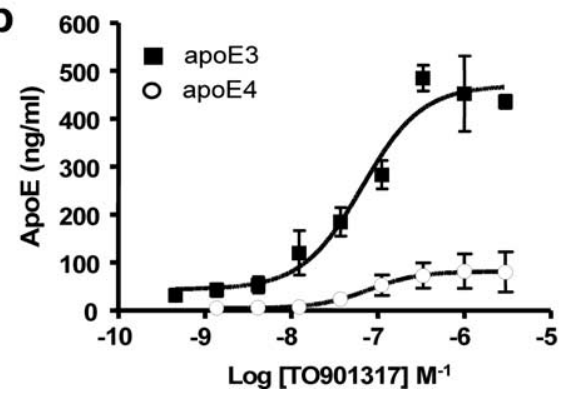

Figure 5. Reduced apoE4 levels in conditioned media from heterozygous human astrocytomas. $\boldsymbol{a}$, CCF-STTG1 cells were cultured in serum-free media for $48 \mathrm{~h}$. The media was removed, apoE-containing lipoproteins isolated by flotation ultracentrifugation (density $<1.21 \mathrm{~g} / \mathrm{ml}$ ) and assayed for total apoE and apoE4 protein levels using the MSD immunoassays as outlined in Materials and Methods $\left(n=3\right.$, mean \pm SEM, $\left.{ }^{* * *} p<0.001\right)$. Because U118 have very low basal levels of apoE secretion, U118 cells $(\varepsilon 2 / 4)$ were cultured in serum-free media containing $1 \mu \mathrm{m}$ T0901317 for $48 \mathrm{~h}$. The media was removed, concentrated 10-fold and assayed for total apoE and apoE4 protein levels using the MSD immunoassays as outlined in Materials and Methods $\left(n=3\right.$, mean \pm SEM, $\left.{ }^{* * *} p<0.001\right)$. $\boldsymbol{b}$, Dose-dependent upregulation of apoE3 and apoE4 by LXR agonist T0901317 in CCF-STTG1 cells. Cells were treated with T0901317 at the indicated concentrations for $48 \mathrm{~h}$. Conditioned media were subjected to total apoE and apoE4 selective immunoassays as described in Materials and Methods. ApoE3 levels were calculated by subtracting apoE4 from total apoE levels. the conditioned media of CCF-STTG1 cells is enhanced cellular retention of apoE4. To examine this possibility we measured apoE levels from CCF-STTG1 cell lysates. Total apoE levels in CCF-STTG1 cell lysates were only $17.9 \pm 1.3 \mathrm{ng} / \mathrm{mg}$ protein compared with $1377 \pm 141 \mathrm{ng} / \mathrm{mg}$ protein secreted into the media over a $24 \mathrm{~h}$ period. As a result of the low levels of cell-associated apoE, apoE4 could not be accurately detected in the cell lysate. Because cellassociated apoE represented $1.3 \pm 0.1 \%$ of total apoE secreted into the media, it is highly unlikely that preferential retention of apoE4 accounts for the differences in secreted apoE levels. Moreover, treating CCF-STTG1 cells with heparinase to release the cell surface bound apoE (Hara et al. 2003) increased the total amount of both apoE3 and apoE4 secreted into the media over a $24 \mathrm{~h}$ period, but it did not significantly alter the ratio of apoE4 to apoE3 (supplemental Fig. S1, available at www.jneurosci.org as supplemental material).

Next, we examined the apoE secretion profiles from $\varepsilon 3 / 3, \varepsilon 3 / 4$ and $\varepsilon 4 / 4$ primary astrocytic cultures. Astrocytes from $\varepsilon 4 / 4$ mice secreted $28 \pm 8.4 \%$ less apoE into the culture medium than $\varepsilon 3 / 3$ cultures $(n=6, p<0.05)$. Moreover, when we examined the relative contribution of apoE4 to total apoE levels secreted from primary astrocytes obtained from human $\varepsilon 3 / 4$ targeted replacement mice, and consistent with the human astrocytoma and in vivo data, apoE4 only represented only $31.1 \pm 1.8 \%$ of the total apoE pool $(n=3, p<0.001)$. Finally, there was a genotype-dependent decrease in cholesterol secreted into the medium, $\varepsilon 3 / 3>\varepsilon 3 / 4>\varepsilon 4 / 4(n=3-9$ per group, $p<0.001$; one-way ANOVA), with $\varepsilon 3 / 4$ showing a $18.2 \pm$ $6.2 \%$ and $\varepsilon 4 / 4$ showing a $52.0 \pm 10.7 \%$ decrease in cholesterol relative to $\varepsilon 3 / 3$.

It has previously been shown that apoE can undergo significant intracellular degradation and thus escape secretion in macrophages, hepatocytes and CHO cells (Ye et al., 1993; Deng et al., 1995). To investigate this possibility as the basis for the isoformrelated differences in apoE secretion in astrocytes, the kinetics of apoE secretion and degradation in $\varepsilon 3 / 3$ and $\varepsilon 4 / 4$ primary astrocytes was measured by means of $\left[{ }^{35} \mathrm{~S}\right]$-pulse-chase experiments. Analysis of residual cell ${ }^{35} \mathrm{~S}$-labeled apoE during chase incubations demonstrated that $\left[{ }^{35} \mathrm{~S}\right]$-apoE4 disappeared more rapidly from the astrocytes than $\left[{ }^{35} \mathrm{~S}\right]$-apoE3 $(p=0.0083$, two-way ANOVA) (Fig. 6a). Cell-associated apoE4 had a half-life of 49 min compared with $96 \mathrm{~min}$ for apoE3. Net degradation of apoE was significantly higher in $\varepsilon 4 / 4$ cultures ( $p=0.0045$, two-way ANOVA) (Fig. 6c), with $43.1 \pm 4.4 \%$ of apoE4 degraded after a 120 min chase, compared with $21.6 \pm 7.9 \%$ for apoE3. This increased degradation of apoE4 corresponded with a decreased secretion of apoE4 after a 300 min chase $(p<0.05$, two-way ANOVA) (Fig. 6b). As previously noted for macrophages (Kockx et al., 2004), newly synthesized astrocytic apoE appears to be present in two distinct pools, a stable pool of cell-associated apoE $(\sim 30 \%)$, that is neither secreted nor degraded over the duration of the experiment, and a mobile pool of apoE $(\sim 70 \%)$ that is targeted for either secretion or intracellular degradation. Inter- 
estingly, although apoE4 is degraded faster than apoE3, the secretion rate of apoE4 appears to be maintained at apoE3 levels for the first $120 \mathrm{~min}$ of the chase, after which the secretion of apoE4 drops off relative to apoE3 (Fig. 6b). It is of note that at the 120 min time point, the mobile pool of apoE4 appears to be completely exhausted, whereas apoE3 cells still have capacity in their mobile pool for either secretion or degradation (Fig. 6a). These data suggest that despite the enhanced rate of degradation, the apoE4 astrocytes maintain normal rates of apoE secretion until all available apoE is depleted. Ultimately, at the end of the 300 min chase period, $27.8 \pm 2.7 \%$ of newly synthesized apoE3 has been secreted into the media and $41.0 \pm 4.1 \%$ has been degraded, compared with $18.9 \pm 2.5 \%$ of apoE4 being secreted and $51.7 \pm 4.0 \%$ degraded (Fig. 6d). These data correspond very well with the $28 \%$ reduction of total apoE detected in the media of E4/4 astrocytes by immunoassay.

Recent evidence suggest that apoE4 is preferentially susceptible to proteolytic degradation into cytotoxic fragments (Huang et al., 2001), we therefore wished to determine whether the enhanced degradation of apoE4 led to an accumulation of the cytotoxic fragments in the astrocytes and brains of $\varepsilon 4 / 4$ mice. Although a low level of both 22 and $10 \mathrm{kDa}$ fragments were detected in the pulse-chase experiments, these fragments degraded at the same rate as full-length apoE and did not accumulate in either $\varepsilon 3 / 3$ or $\varepsilon 4 / 4$ cells (data not shown). Moreover, using Western blotting, and despite heavily over-exposing our blots, we could find no evidence of the accumulation of apoE4 selective degradation products in the hippocampus of the $\varepsilon 4 / 4$ mice (supplemental Fig. S2, available at www.jneurosci.org as supplemental material).

\section{Discussion}

In humans and animal models, apoE genotype is correlated with apoE protein levels in plasma, with $\varepsilon 2$ showing the highest protein levels and $\varepsilon 4$ the lowest (Eto et al., 1986; Gregg et al., 1986; Raffai et al., 2001) (Fig. 2). In plasma, apoE4 preferentially binds to large, triglyceride-rich, very low-density lipoproteins and is more rapidly catabolized by the liver, thus leading to low steady state plasma levels. The effect of the $\varepsilon 4$ allele on the locally synthesized CNS apoE protein levels is less clear with multiple conflicting reports showing either reduced levels (Bertrand et al., 1995; Beffert et al., 1999; Glöckner et al., 2002; Poirier, 2005; Ramaswamy et al., 2005), no change (Sullivan et al., 2004; Fryer et al., 2005) or increases (Fukumoto et al., 2003) in apoE from both $\mathrm{AD}$ patient $\mathrm{CNS}$ and animal models. In this study, we have extensively analyzed the effect of the $\varepsilon 4$ allele on apoE levels both in vitro and in vivo. To avoid artifactual measurements of apoE4 relative to apoE2 and apoE3, we used multiple methods of apoE enrichment (lipoprotein isolation, filtration concentration and LXR agonist induction) and detection (immunoassay and Western blot). We also detergent extracted plasma, CSF and brain samples before quantification, thus precluding well known issues of apolipoprotein detection in aqueous solutions (Krul and Cole, 1996; Ramaswamy et al., 2005). Finally, we measured relative levels of both total apoE and apoE4 in $\varepsilon 3 / 4$ heterozygous cell lines and primary astrocytic cultures, as well as, in mouse plasma, CSF and brains, establishing a ratio of total apoE to apoE4 in each individual sample and thus providing a strong internal control. Together, our data show that the human $\varepsilon 4$ allele is preferentially degraded in astrocytes, leading to a reduced level of apoE protein and cholesterol secretion and low steady state brain and CSF levels of apoE in transgenic animals.

Although the mechanisms that lead to increases in CNS, apoE2 levels have been previously explored (Mann et al., 2004; Fryer et al., 2005) and appear to be related to the inability of apoE2 to bind to the LDL receptor (Fryer et al., 2005), the mechanisms that leads to low levels of CNS apoE4 are less clear. In vivo, the lower levels of apoE4 were not attributable to decreased mRNA levels, suggesting a post-translational mechanism. Indeed, we observed a consistent decrease in the level of apoE4 secreted into the media of primary astrocytes and human astrocytomas. This reduction in apoE4 levels was not apparently attributable to enhanced cellular retention of apoE4 but rather an accelerated intracellular degradation of newly synthesized apoE4. One potential mechanism to explain this observation is that the cellular quality control machinery recognizes apoE4 as a misfolded protein and targets it for degradation. Indeed, it is known from in vitro observations that apoE4 is the least stable of all the apoE isoforms: apoE4 denatures at lower concentrations of urea and at lower temperatures, whereas the denaturation pattern of apoE4 suggests that it can exist as a partially folded intermediate or a molten globule state (Morrow et al., 2002). Interestingly, the 
stabilization of a molten globule state caused by point mutations in the cystic fibrosis transmembrane conductance regulator gene is known to target this protein for enhanced degradation (Santucci et al., 2008).

The main focus of research into the role of apoE4 in $\mathrm{AD}$ has concentrated on the ability of apoE to influence the metabolism of the peptidic neurotoxin, $A \beta$, that accumulates in the brain of $\mathrm{AD}$ patients. A large number of in vitro and in vivo studies have suggested that endogenous CNS-derived apoE-containing lipoprotein particles bind to $\mathrm{A} \beta$ and promote its clearance and degradation (DeMattos et al., 2004; Koistinaho et al., 2004; Manelli et al., 2004; Stratman et al., 2005; Trommer et al., 2005) and that apoE 4 carriers have increased $\mathrm{A} \beta$ burden (Beffert et al., 1999; Corder et al., 2004; Fryer et al., 2005). Our data suggests that low brain levels of apoE4 relative to apoE3 may contribute to raised $\mathrm{A} \beta$ levels, because the low apoE levels in $\varepsilon 4$ carriers may reduce the clearance efficiency of the $\mathrm{A} \beta$ peptide and thus accelerate its subsequent deposition. Indeed, recent studies by our group and others have shown that dosing of APP transgenic mice with LXR agonists, which increase murine CNS apoE levels, also decrease A $\beta$ levels (Koldamova et al., 2005; Burns et al., 2006; Riddell et al., 2007). It will be interesting to determine whether the LXR compounds can reduce the $\mathrm{A} \beta$ burden in $\varepsilon 4 / 4$ mice crossed with the APP transgenic animals.

Although this apoE/A $\beta$ interaction may account for the strong association of $\varepsilon 4$ with $\mathrm{AD}$, it cannot fully explain the apparent association of apoE with a range of neurological disorders that do not exhibit an accumulation of the $\mathrm{A} \beta$ peptide. One alternative hypothesis recently proposed suggests that apoE4 is preferentially susceptible to proteolytic degradation into cytotoxic fragments (Huang et al., 2001; Brecht et al., 2004). Although degradation of apoE4 to cytotoxic N-terminal fragments is an attractive CNS-dependent mechanism to account both for the low levels of apoE detected in the brains of $\varepsilon 4$ mice and neurodegeneration, we could not detect the accumulation of any such fragments in our cultures or brain homogenates. Nevertheless, it should be noted that one cannot rule out the possibility that the apoE fragments may preferentially accumulate in the disease state and not in the healthy young animals examined in this study.

One additional important role that apoE may play in the CNS is in the delivery of cholesterol to neurons. The neuronal synapse is a cholesterol-rich organelle (Pfrieger, 2003) and astrogliaderived cholesterol has been shown to be essential in maintaining neuronal health by promoting synaptogenesis (Mauch et al., 2001) and neurite outgrowth (Handelmann et al., 1992; Nathan et al., 1994). Moreover, it has been hypothesized that because apoE is dramatically upregulated after neuronal injury, that the ability of apoE to deliver cholesterol to regenerating neurons may be an important factor in cognitive recovery from brain injury (Poirier, 1994). Multiple in vivo studies support this claim: for example, it has been demonstrated that apoE knock-out mice and $\varepsilon 4 / 4$ targeted replacement mice exhibit more severe neurological and cognitive deficits after closed head injury (Chen et al., 1997; Sabo et al., 2000), experimental stroke (Laskowitz et al., 1997; Sheng et al., 1998, 1999), entorhinal cortex lesions (Fagan et al., 1998; White et al., 2001) and experimental allergic encephalomyelitis (Karussis et al., 2003) than controls (wild-type and $\varepsilon 3 / 3$ mice, respectively). Moreover, it has also been noted that the presence of the $\varepsilon 4$ allele correlates with a reduced number of dendritic spines in transgenic mice and $\mathrm{AD}$ patients (Ji et al., 2003; Lai et al., 2006). These studies suggest that $\varepsilon 4 / 4$ mice display a similar phenotype to the apoE knock-out and that, at least with respect to plasticity, apoE4 has characteristics of a "loss of function" mutation. Our data, together with the work of Ramaswamy et al. (2005), suggests that the preferential degradation of apoE4 relative to apoE3 in astrocytes leads to a reduced capacity for the delivery of cholesterol the neurons for repair and that this phenotype may ultimately underlie this plasticity loss of function. Indeed, the diverse array of neurological conditions that exhibit very distinct neuropathology but implicate $\varepsilon 4$ as a risk factor, imply that the apoE4 protein may not harbor any direct pathological actions contributing to the underlying neurodegenerative processes but rather that apoE4 lacks the protective effects of apoE3. Although additional studies are required to identify the exact mechanism leading to the enhanced degradation of intracellular apoE4, these data suggest that pharmacological approaches targeted at stabilizing apoE4 or promoting apoE and/or cholesterol secretion from astrocytes may be potential disease modifying therapies for Alzheimer's disease.

\section{References}

Beffert U, Cohn JS, Petit-Turcotte C, Tremblay M, Aumont N, Ramassamy C, Davignon J, Poirier J (1999) Apolipoprotein E and beta-amyloid levels in the hippocampus and frontal cortex of Alzheimer's disease subjects are disease-related and apolipoprotein E genotype dependent. Brain Res 843:87-94.

Bertrand P, Poirier J, Oda T, Finch CE, Pasinetti GM (1995) Association of apolipoprotein E genotype with brain levels of apolipoprotein E and apolipoprotein J (clusterin) in Alzheimer disease. Brain Res Mol Brain Res 33:174-178.

Boyles JK, Pitas RE, Wilson E, Mahley RW, Taylor JM (1985) Apolipoprotein $\mathrm{E}$ associated with astrocytic glia of the central nervous system and with nonmyelinating glia of the peripheral nervous system. J Clin Invest 76:1501-1513.

Brecht WJ, Harris FM, Chang S, Tesseur I, Yu GQ, Xu Q, Dee Fish J, WyssCoray T, Buttini M, Mucke L, Mahley RW, Huang Y (2004) Neuronspecific apolipoprotein e4 proteolysis is associated with increased tau phosphorylation in brains of transgenic mice. J Neurosci 24:2527-2534.

Burns MP, Vardanian L, Pajoohesh-Ganji A, Wang L, Cooper M, Harris DC, Duff K, Rebeck GW (2006) The effects of ABCAl on cholesterol efflux and Abeta levels in vitro and in vivo. J Neurochem 98:792-800.

Chen Y, Lomnitski L, Michaelson DM, Shohami E (1997) Motor and cognitive deficits in apolipoprotein E-deficient mice after closed head injury. Neuroscience 80:1255-1262.

Corder EH, Saunders AM, Strittmatter WJ, Schmechel DE, Gaskell PC, Small GW, Roses AD, Haines JL, Pericak-Vance MA (1993) Gene dose of apolipoprotein E type 4 allele and the risk of Alzheimer's disease in late onset families. Science 261:921-923.

Corder EH, Ghebremedhin E, Taylor MG, Thal DR, Ohm TG, Braak H (2004) The biphasic relationship between regional brain senile plaque and neurofibrillary tangle distributions: modification by age, sex, and APOE polymorphism. Ann N Y Acad Sci 1019:24-28.

DeMattos RB, Bales KR, Parsadanian M, O’Dell MA, Foss EM, Paul SM, Holtzman DM (2002) Plaque-associated disruption of CSF and plasma $\mathrm{A} \beta$ equilibrium in a mouse model of Alzheimer's Disease. J Neurochem 81:229-236.

DeMattos RB, Cirrito JR, Parsadanian M, May PC, O’Dell MA, Taylor JW, Harmony JA, Aronow BJ, Bales KR, Paul SM, Holtzman DM (2004) ApoE and clusterin cooperatively suppress Abeta levels and deposition: evidence that ApoE regulates extracellular Abeta metabolism in vivo. Neuron 41:193-202.

Deng J, Rudick V, Dory L (1995) Lysosomal degradation and sorting of apolipoprotein E in macrophages. J Lipid Res 36:2129-2140.

Enzinger C, Ropele S, Smith S, Strasser-Fuchs S, Poltrum B, Schmidt H, Matthews PM, Fazekas F (2004) Accelerated evolution of brain atrophy and "black holes" in MS patients with APOE-epsilon 4. Ann Neurol 55:563-569.

Eto M, Watanabe K, Ishii K (1986) Reciprocal effects of apolipoprotein E alleles (epsilon 2 and epsilon 4) on plasma lipid levels in normolipidemic subjects. Clin Genet 29:477-484.

Fagan AM, Murphy BA, Patel SN, Kilbridge JF, Mobley WC, Bu G, Holtzman DM (1998) Evidence for normal aging of the septo-hippocampal cho- 
linergic system in apoE (-/-) mice but impaired clearance of axonal degeneration products following injury. Exp Neurol 151:314-325.

Fazekas F, Strasser-Fuchs S, Kollegger H, Berger T, Kristoferitsch W, Schmidt H, Enzinger C, Schiefermeier M, Schwarz C, Kornek B, Reindl M, Huber K, Grass R, Wimmer G, Vass K, Pfeiffer KH, Hartung HP, Schmidt R (2001) Apolipoprotein E epsilon 4 is associated with rapid progression of multiple sclerosis. Neurology 57:853-857.

Fernández-Miranda C, Cancelas P, de la Calle A, Gómez R, Moreno E, Gómez-Gerique J, del Palacio A (1997) Changes in phenotypes of apolipoprotein E and apolipoprotein(a) in liver transplant recipients. Clin Transplant 11:325-327.

Friedman G, Froom P, Sazbon L, Grinblatt I, Shochina M, Tsenter J, Babaey S, Yehuda B, Groswasser Z (1999) Apolipoprotein E-epsilon4 genotype predicts a poor outcome in survivors of traumatic brain injury. Neurology 52:244-248.

Fryer JD, Simmons K, Parsadanian M, Bales KR, Paul SM, Sullivan PM, Holtzman DM (2005) Human apolipoprotein E4 alters the amyloidbeta 40:42 ratio and promotes the formation of cerebral amyloid angiopathy in an amyloid precursor protein transgenic model. J Neurosci 25:2803-2810.

Fukumoto H, Ingelsson M, Gårevik N, Wahlund LO, Nukina N, Yaguchi Y, Shibata M, Hyman BT, Rebeck GW, Irizarry MC (2003) APOE epsilon 3/ epsilon 4 heterozygotes have an elevated proportion of apolipoprotein E4 in cerebrospinal fluid relative to plasma, independent of Alzheimer's disease diagnosis. Exp Neurol 183:249-253.

Glöckner F, Meske V, Ohm TG (2002) Genotype-related differences of hippocampal apolipoprotein E levels only in early stages of neuropathological changes in Alzheimer's disease. Neuroscience 114:1103-1114.

Gregg RE, Zech LA, Schaefer EJ, Stark D, Wilson D, Brewer HB Jr (1986) Abnormal in vivo metabolism of apolipoprotein E4 in humans. J Clin Invest 78:815-821.

Guerrero AL, Laherrán E, Gutiérrez F, Martín-Polo J, Iglesias F, Alcázar C, Peralta J, Rostami P (2008) Apolipoprotein E genotype does not associate with disease severity measured by Multiple Sclerosis Severity Score. Acta Neurol Scand 117:21-25.

Handelmann GE, Boyles JK, Weisgraber KH, Mahley RW, Pitas RE (1992) Effects of apolipoprotein E, beta-very low density lipoproteins, and cholesterol on the extension of neurites by rabbit dorsal root ganglion neurons in vitro. J Lipid Res 33:1677-1688.

Hara M, Matsushima T, Satoh H, Iso-o N, Noto H, Togo M, Kimura S, Hashimoto Y, Tsukamoto K (2003) Isoform-dependent cholesterol efflux from macrophages by apolipoprotein $\mathrm{E}$ is modulated by cell surface proteoglycans. Arterioscler Thromb Vasc Biol 23:269-274.

Hatters DM, Peters-Libeu CA, Weisgraber KH (2006) Apolipoprotein E structure: insights into function. Trends Biochem Sci 31:445-454.

Hixson JE, Vernier DT (1990) Restriction isotyping of human apolipoprotein $\mathrm{E}$ by gene amplification and cleavage with HhaI. J Lipid Res 31:545-548.

Huang Y, Liu XQ, Wyss-Coray T, Brecht WJ, Sanan DA, Mahley RW (2001) Apolipoprotein E fragments present in Alzheimer's disease brains induce neurofibrillary tangle-like intracellular inclusions in neurons. Proc Natl Acad Sci U S A 98:8838-8843.

Jasinska-Myga B, Opala G, Goetz CG, Tustanowski J, Ochudlo S, Gorzkowska A, Tyrpa J (2007) Apolipoprotein E gene polymorphism, total plasma cholesterol level, and Parkinson disease dementia. Arch Neurol 64:261-265.

Ji Y, Gong Y, Gan W, Beach T, Holtzman DM, Wisniewski T (2003) Apolipoprotein $\mathrm{E}$ isoform-specific regulation of dendritic spine morphology in apolipoprotein E transgenic mice and Alzheimer's disease patients. Neuroscience 122:305-315.

Karussis D, Michaelson DM, Grigoriadis N, Korezyn AD, Mizrachi-Koll R, Chapman S, Abramsky O, Chapman J (2003) Lack of apolipoprotein-E exacerbates experimental allergic encephalomyelitis. Mult Scler 9:476-480.

KnouffC, Hinsdale ME, Mezdour H, Altenburg MK, Watanabe M, Quarfordt SH, Sullivan PM, Maeda N (1999) Apo E structure determines VLDL clearance and atherosclerosis risk in mice. J Clin Invest 103:1579-1586.

Kockx M, Rye KA, Gaus K, Quinn CM, Wright J, Sloane T, Sviridov D, Fu Y, Sullivan D, Burnett JR, Rust S, Assmann G, Anantharamaiah GM, Palgunachari MN, Katz SL, Phillips MC, Dean RT, Jessup W, Kritharides L (2004) Apolipoprotein A-I-stimulated apolipoprotein E secretion from human macrophages is independent of cholesterol efflux. J Biol Chem 279:25966-25977.

Koistinaho M, Lin S, Wu X, Esterman M, Koger D, Hanson J, Higgs R, Liu F, Malkani S, Bales KR, Paul SM (2004) Apolipoprotein E promotes astrocyte colocalization and degradation of deposited amyloid-beta peptides. Nat Med 10:719-726.

Koldamova RP, Lefterov IM, Staufenbiel M, Wolfe D, Huang S, Glorioso JC, Walter M, Roth MG, Lazo JS (2005) The liver X receptor ligand T0901317 decreases amyloid beta production in vitro and in a mouse model of Alzheimer's disease. J Biol Chem 280:4079-4088.

Krul ES, Cole TG (1996) Quantitation of apolipoprotein E. Methods Enzymol 263:170-187.

LaDu MJ, Gilligan SM, Lukens JR, Cabana VG, Reardon CA, Van Eldik LJ, Holtzman DM (1998) Nascent astrocyte particles differ from lipoproteins in CSF. J Neurochem 70:2070-2081.

Lai MK, Tsang SW, Garcia-Alloza M, Minger SL, Nicoll JA, Esiri MM, Wong PT, Chen CP, Ramirez MJ, Francis PT (2006) Selective effects of the APOE epsilon 4 allele on presynaptic cholinergic markers in the neocortex of Alzheimer's disease. Neurobiol Dis 22:555-561.

Laskowitz DT, Sheng H, Bart RD, Joyner KA, Roses AD, Warner DS (1997) Apolipoprotein E-deficient mice have increased susceptibility to focal cerebral ischemia. J Cereb Blood Flow Metab 17:753-758.

Liang Y, Lin S, Beyer TP, Zhang Y, Wu X, Bales KR, DeMattos RB, May PC, Li SD, Jiang XC, Eacho PI, Cao G, Paul SM (2004) A liver X receptor and retinoid $\mathrm{X}$ receptor heterodimer mediates apolipoprotein $\mathrm{E}$ expression, secretion and cholesterol homeostasis in astrocytes. J Neurochem 88:623-634.

Manelli AM, Stine WB, Van Eldik LJ, LaDu MJ (2004) ApoE and Abeta1-42 interactions: effects of isoform and conformation on structure and function. J Mol Neurosci 23:235-246.

Mann KM, Thorngate FE, Katoh-Fukui Y, Hamanaka H, Williams DL, Fujita S, Lamb BT (2004) Independent effects of APOE on cholesterol metabolism and brain Abeta levels in an Alzheimer disease mouse model. Hum Mol Genet 13:1959-1968.

Marriott DR, Hirst WD, Ljungberg MC (1995) Astrocytes. In: Neural cell culture-a practical approach (Cohen J, Wilkin GP, eds), pp 85-96. Oxford: Oxford UP.

Mauch DH, Nägler K, Schumacher S, Göritz C, Müller EC, Otto A, Pfrieger FW (2001) CNS synaptogenesis promoted by glia-derived cholesterol. Science 294:1354-1357.

Morrow JA, Hatters DM, Lu B, Hochtl P, Oberg KA, Rupp B, Weisgraber KH (2002) Apolipoprotein E4 forms a molten globule. A potential basis for its association with disease. J Biol Chem 277:50380-50385.

Moulard B, Sefiani A, Laamri A, Malafosse A, Camu W (1996) Apolipoprotein E genotyping in sporadic amyotrophic lateral sclerosis: evidence for a major influence on the clinical presentation and prognosis. J Neurol Sci 139 [Suppl]:34-37.

Nathan BP, Bellosta S, Sanan DA, Weisgraber KH, Mahley RW, Pitas RE (1994) Differential effects of apolipoproteins E3 and E4 on neuronal growth in vitro. Science 264:850-852.

O’Donnell HC, Rosand J, Knudsen KA, Furie KL, Segal AZ, Chiu RI, Ikeda D, Greenberg SM (2000) Apolipoprotein E genotype and the risk of recurrent lobar intracerebral hemorrhage. N Engl J Med 342:240-245.

Pankratz N, Byder L, Halter C, Rudolph A, Shults CW, Conneally PM, Foroud T, Nichols WC (2006) Presence of an APOE4 allele results in significantly earlier onset of Parkinson's disease and a higher risk with dementia. Mov Disord 21:45-49.

Pfrieger FW (2003) Role of cholesterol in synapse formation and function. Biochim Biophys Acta 1610:271-280.

Poirier J (1994) Apolipoprotein E in animal models of CNS injury and in Alzheimer's disease. Trends Neurosci 17:525-530.

Poirier J (2005) Apolipoprotein E, cholesterol transport and synthesis in sporadic Alzheimer's disease. Neurobiol Aging 26:355-361.

Quinet EM, Savio DA, Halpern AR, Chen L, Miller CP, Nambi P (2004) Gene-selective modulation by a synthetic oxysterol ligand of the liver $\mathrm{X}$ receptor. J Lipid Res 45:1929-1942.

Raber J, Huang Y, Ashford JW (2004) ApoE genotype accounts for the vast majority of AD risk and AD pathology. Neurobiol Aging 25:641-650.

Raffai RL, Dong LM, Farese RV Jr, Weisgraber KH (2001) Introduction of human apolipoprotein E4 "domain interaction" into mouse apolipoprotein E. Proc Natl Acad Sci U S A 98:11587-11591.

Ramaswamy G, Xu Q, Huang Y, Weisgraber KH (2005) Effect of domain 
interaction on apolipoprotein $\mathrm{E}$ levels in mouse brain. J Neurosci 25:10658-10663.

Riddell DR, Zhou H, Comery TA, Kouranova E, Lo CF, Warwick HK, Ring RH, Kirksey Y, Aschmies S, Xu J, Kubek K, Hirst WD, Gonzales C, Chen Y, Murphy E, Leonard S, Vasylyev D, Oganesian A, Martone RL, Pangalos MN, Reinhart PH, Jacobsen JS (2007) The LXR agonist TO901317 selectively lowers hippocampal Abeta42 and improves memory in the Tg2576 mouse model of Alzheimer's disease. Mol Cell Neurosci 34:621-628.

Sabo T, Lomnitski L, Nyska A, Beni S, Maronpot RR, Shohami E, Roses AD, Michaelson DM (2000) Susceptibility of transgenic mice expressing human apolipoprotein E to closed head injury: the allele E3 is neuroprotective whereas E4 increases fatalities. Neuroscience 101:879-884.

Santucci R, Sinibaldi F, Fiorucci L (2008) Protein folding, unfolding and misfolding: role played by intermediate States. Mini Rev Med Chem 8:57-62.

Schneider JA, Bienias JL, Wilson RS, Berry-Kravis E, Evans DA, Bennett DA (2005) The apolipoprotein E epsilon4 allele increases the odds of chronic cerebral infarction [corrected] detected at autopsy in older persons. Stroke 36:954-959.

Sheng H, Laskowitz DT, Mackensen GB, Kudo M, Pearlstein RD, Warner DS (1999) Apolipoprotein E deficiency worsens outcome from global cerebral ischemia in the mouse. Stroke 30:1118-1124.

Sheng H, Laskowitz DT, Bennett E, Schmechel DE, Bart RD, Saunders AM, Pearlstein RD, Roses AD, Warner DS (1998) Apolipoprotein E isoform- specific differences in outcome from focal ischemia in transgenic mice. J Cereb Blood Flow Metab 18:361-366.

Siddique T, Pericak-Vance MA, Caliendo J, Hong ST, Hung WY, Kaplan J, McKenna-Yasek D, Rimmler JB, Sapp P, Saunders AM, Scott WK, Siddique N, Haines JL, Brown RH (1998) Lack of association between apolipoprotein E genotype and sporadic amyotrophic lateral sclerosis. Neurogenetics 1:213-216.

Stratman NC, Castle CK, Taylor BM, Epps DE, Melchior GW, Carter DB (2005) Isoform-specific interactions of human apolipoprotein E to an intermediate conformation of human Alzheimer amyloid-beta peptide. Chem Phys Lipids 137:52-61.

Sullivan PM, Mace BE, Maeda N, Schmechel DE (2004) Marked regional differences of brain human apolipoprotein E expression in targeted replacement mice. Neuroscience 124:725-733.

Trommer BL, Shah C, Yun SH, Gamkrelidze G, Pasternak ES, Stine WB, Manelli A, Sullivan P, Pasternak JF, LaDu MJ (2005) ApoE isoformspecific effects on LTP: blockade by oligomeric amyloid-beta1-42. Neurobiol Dis 18:75-82.

Weisgraber KH, Mahley RW (1996) Human apolipoprotein E: the Alzheimer's disease connection. Faseb J 10:1485-1494.

White F, Nicoll JA, Roses AD, Horsburgh K (2001) Impaired neuronal plasticity in transgenic mice expressing human apolipoprotein E4 compared to E3 in a model of entorhinal cortex lesion. Neurobiol Dis 8:611-625.

Ye SQ, Reardon CA, Getz GS (1993) Inhibition of apolipoprotein E degradation in a post-Golgi compartment by a cysteine protease inhibitor. J Biol Chem 268:8497-8502. 